\title{
The political aesthetic of the British city-state: Class formation through the global city
}

\author{
John Welsh \\ Department of Political and Economic Studies, University of Helsinki, Helsinki, Finland \\ Correspondence \\ John Welsh, Snellmaninkatu 14A, Helsinki 00014, Finland. \\ Email:john.welsh@helsinki.fi
}

\begin{abstract}
So the city state metaphor highlights key distinguishing features of autonomy and authority which have strengthened London's distinctive identity in the last thirty years and made its relation to the national host increasingly problematic (Ertürk et al., 2011, p. 7).
\end{abstract}

\section{1 | INTRODUCTION: THE POLITICAL PROBLEM}

Over the last 30 years of strategic reconfiguration in the British state, we have become confronted with an international revanchist capitalist class across the core states of the world system, and a resurgent domestic metropolitan power, in a manner that is markedly historical, geographical, and political. If we are to contemplate new emancipatory trajectories, this reconfiguration calls for urgent reconceptualization not only of the "inherited metageographical assumptions" of urban sociology (Brenner \& Schmid, 2017, p. 187), but also of the social relations that constitute the new conditions of existence in our state-territory. So, what is this new condition?

The Conservative Party's rehashing of the One-Nation Britain slogan seems to bear no relation to the country we actually inhabit (Elliott, 2013), with the recent EU referendum result symptomatizing the widening cleavages left by Austerity and a generation of neoliberalization. The dominance of the City of London has hollowed out industry across the country (Jessop, 1994), and has contracted the social skill base (Elliott, 2011), with "generally negative macroeconomic effects on the state territory as a whole" (Agnew, 2005, p. 444). A new generation of boosterish buildings that pepper the world's greatest tax haven has turned our seat of government into "a pastiche of the Gulf economy" (Jenkins, 2013) and has made a mockery of the calls for Austerity. British government seems now to cater for the febrile advantage of financiers, mediacrats, and property spivs avant le deluge, culturally reinforced by an echeloned cadre of ideological apologists of pan-global provenance, whose social, cultural, and political orientations "now link them to other financial centres than to their nominal home states" (Agnew, 2005, p. 444).

It is the dominant liberal discourse of the "city," which assumes London to be a place of productive potency and wealth creation, that I want fundamentally to reconsider as a political apologetic for the domination of metropolitan power positionalities that rather appropriate, command, and dispose the disbursements of capital. As such, it has been forgotten in these discourses that the classical city-state was built on hierarchy, exploitation, slavery, leisure, a profoundly ambiguous and contested imagined community, and a brutal disregard for individual human life (Anderson, 2013, pp. 21-22; Long, 1972, p. 26). The class politics of the city-state differ quite considerably from those of industrial production across the national territory. The mysterious osmosis of trickle-down economics, putatively centrifugal, 
and an inflated sense of their own indispensability on the part of an insular dominant class, flow into a projected image of London as the national breadwinner, the primum movens, the "powerhouse of the UK economy" (Pickford, 2013, p. 2). It is as though the heroic age of capitalism has returned, but what is patent is how crypto-feudal our society has actually become. So, to undermine this productivist vision I suggest using terms that are more germane to an oligarchic or even aristocratic metropolitan power: appropriation, dispossession, rent, enclosure, toll, domination, extraction, hierarchy, trap, waste, levy, immobility, tribute, anti-production, and dissipation. Laying out how the dominant liberal vision has become politically reactionary is the task ahead. We must calibrate our critical crosshairs once again at a territorialized property power and not simply allow our energy to be diverted into the "insipid humanism" that fixates on managing poverty from the post-national hub (Harvey, 2015, p. 285-293). Briefly stated, in the newly territorialized political economy of what I shall call, the axiomatic city-state, ${ }^{1}$ we must rediscover the political form of class struggle and counter conduct that has begun to emerge from the changing constellation of social forces in the spatio-temporal particularity of the British polity, and ask ourselves what we are going to do about it.

In critical and democratic theory it has become politically exigent to penetrate analytically the formation and operation of this metropolitan oligarchy by focusing on more than a mere cabal of bankers and politicians who control the principal organs of executive decision-making, and to think beyond the City as the source of all our woes. A cultural and ideological pseudo-cosmopolitan elite beyond conventional delimitation buttresses the financial interest through their manipulation of the new metropolitan positionalities of surplus appropriation. They are implicated in an expanded notion of financialization that is semiotic and territorial. Despite their nominally progressive politics, and internationalist leanings, they are metropolitan agents of global capital as a new urban oligarchy, ${ }^{2}$ and as such are constitutive fractions of the international capitalist class.

What is now necessary is to engage in some imaginative and critical thinking on how and why London-UK, as an assemblage of social relations that goes way beyond the conventionally understood geographical expression, constitutes a spatio-temporal ligature that mediates the British state-territory in the world system. We must acknowledge that there is something in the character of this assemblage that facilitates the emplacement of positionalities of appropriation, and how it has become generative of new constellations of class. Most important of all, we must foreground the contradictions in the dominant liberal ideology of the city, and in so doing shed light on the path to servitude, domination, dispossession, and enforced inertia that is the chronic reality for those of us unfortunate enough to have been born into parochial obscurity.

The obviousness and clarity with which these developments strike those who live in Britain today is only equalled at present by a baffled confusion over the course of recent events. These evental features of British politics symptomatize the developmental conjoncture (in the Annales sense of the term), ${ }^{3}$ about which this article is concerned, and by reference to which these events can be more clearly interpreted. What are some of these events?

Prolonged neoliberalization has been feebly opposed and has been devastating to provincial Britain (Agnew, 2005, p. 444; Jessop, 1994). The reinvigoration of the project in endless Austerity has passed the point of a short-term remedy in the aftermath of 2008 and has now, 10 years later, quite clearly become a new idiom of political economy for the years ahead, with profound political and geographical characteristics. Another development is the growth in support for the United Kingdom Independence Party (UKIP) at the ballot boxes, cutting across fetishized political cartographies and cherished class categories that were familiar to the industrial state-territory. Instead, it draws upon disaffection with the new political geography of the British polity, provoking the sense that this development is bound into the relocation of political and cultural power in the state-territory. In similar way, the Scottish Independence referendum and the turn to the Scottish National Party ought not be mistaken for yet another European breed of ethno-nationalism. Rather, it seems that its support lies in the reconfigurations of the British state-territory tht have taken place since the 1980s finally bearing fruit in the catalyst of Austerity politics. Once again, disaffection with the new political economic idiom of the British state-territory seems to indicate the growth in Scotland of a pseudo-national, class-based self-determination vis-à-vis the metropolitan power. Finally, there is Brexit. Popular self-determination arguments for the Brexit referendum outcome are highly problematic, which seems to resemble an affective reorientation of antiestablishment ressentiment onto a vague and contrived extra-national other, more than it articulates popular disaffection with EU government in particular. 
I want to try to bring these developments in contemporary British politics into some kind of relation to one another, as these events of varying temporality are currently treated in isolation. This analyses therefore remains decidedly evental. The problem underlying these events is that there has been a reconfiguration in the topology and topography of the power that dominates the state-territory, which requires a new political geographical understanding. This political geography requires articulation and the exploration of fresh avenues of political theorizing, if we want to develop a critical $21^{\text {st }}$ century urban theory through the exploration of particular contexts. By laying out what we might call the new political aesthetic of the British state, not only will we make the interrelation of these evental political features more apparent, rendering each event more intelligible, but we may discern a rather different strategic set of responses to them that are not only plausible but manifestly necessary for those who wish to confront the power of capital in the British state. This argument therefore has significant implications for reconceptualizing class formation in post-industrial political geographies dominated by global cities.

The desired effect is to start us thinking on how seemingly national social relations can rather be understood as class social relations, and thus how the resurgence of apparently ethno-nationalist politics entails, contains and canalizes a new form of anti-establishment class politics with possibilities and potentials for radical and critical orientations propitious for genuinely progressive political action.

I use the concept of a British city-state as an opening gambit for rethinking political spatiality in the current British social experience. If we are to derive a radical politics of thought-action, resistance to or strategic counter-conduct against the oligarchic metropolitan power that I claim has arisen through the constitution of this new spatiality, we must do this in a way that is simultaneously (i) novel enough to enable innovative theorizing of those "new geographical metaphors and concepts" so necessary for grasping "emergent, post-Westphalian political geographies" (Anderson, 1996, p. 151; Brenner, 1999, p. 67); and yet (ii) that is resonating and familiar enough to recognize intuitively and grasp practically, so as to be credibly "turned against the heavy arms of the State" as a weapon (Deleuze \& Guattari, 2013, p. 239).

This analysis proceeds in accord with the objectives of the "critical urban theory" that is currently emerging in sociological discourses of urbanization and that seeks to combat the "epistemology of 'naïve objectivism" so prevalent in thinking on political geographical questions. In trying to think beyond "inherited, naturalized jurisdictional and sociological visions" (Arboleda, 2017, p. 11), critical urban theory pushes for an epistemological reorientation away from categorical unities and towards social relations in analysis, a move that is congenial to the "constant reinvention of the framing categories, methods and assumptions of critical urban theory in relation to the rapidly, unevenly mutating geographies of capitalist urbanization, especially in the contemporary era of hyperfinancialized, planetaryscale spatial, institutional and ecological transformation" (Brenner, 2017a, p. 22). Particularly relevant here to the city-hinterland representation is the struggle in critical urban theory to depart from ahistorical dualisms and binaries like interior/exterior, city/countryside, urban/rural, society/nature, material/symbolic and of course city/hinterland (Brenner, 2017b, p. 218, 2017c, p. 265; Brenner \& Schmid, 2015). Instead, a more critically potent dialectical mode is sought, which replaces the scientistic penchant for metaphysical commitments with those radical conceptualizations necessary for strategic orientations in political and intellectual struggle (Brenner, 2017c, p. 264).

In this light, it is evident that terms such as city, urban, urbanization, nation, state, and so on, are highly problematic and cannot be "conceived as self-evident empirical entities that can be transparently understood and instrumentally manipulated by a neutral observer occupying a vantage point external to the sites and processes being investigated" (Brenner, 2017a, p. 20). While there is no space here to navigate all these terms satisfactorily, I have had to use these terms provisionally to anchor the analysis in sufficiently familiar terms to be understood. In what follows, terms such as city, urban, and urbanization should be treated as part of a "sociology of relations", rather than a "sociology of categories" (Welsh, 2018), and should be so interpreted to the extent that they facilitate this direction of meaning. This is essential for understanding the processes, ambiguities, asymmetries, and uneven developments that are central to this critical project.

Through a somewhat abstract political economy, I am trying to innovate a historical and geographical consciousness of social practice that relates the particularities of the British state to its broader social and economic spatial structures and to the geopolitical order in a way that gets us past the "reification of state territorial spaces as fixed [ahistorical] 
units of secure sovereign space" that conceptually rule out "spatial variation other than between homogeneous blocks of territorial space" (Agnew, 1994, p. 77; 1996, p. 1929). This is the critical agenda here, and it is the principal intervention I intend to make in academic discourses on political spatio-temporality. At the heart of this lies an account of how shifting the register from a spatial to a territorial analytical idiom, bracketing scale, space, and network for the moment (see Jessop, Brenner, \& Jones, 2008), accompanied by an elaboration of what this actually means in terms of existing discourses of historical sociology and political geography, which will open the door to a more pertinent vector of critique of the political status quo.

To clarify, the background political argument here is that the strategic and implicitly territorial redefinitions of positionality and relationality in the British state are intimately bound into: (i) the rise of metropolitan oligarchy in Britain; (ii) its capture of the state apparatus, broadly defined; (iii) the consequent and instrumental reconfiguration of the British state-territory into a contado ${ }^{4}$ of the metropole; (iv) the legitimation of metropolitan dominance by a liberal ideology of the city; and ( $v$ ) the ideological canalization of resistance to this new oligarchy into a regressive politics of jingoism, populist nationalism, and a perverse discourse of English self-determination. To begin this agenda, I shall introduce three conceptualizations-one principal and two subsidiary-pertaining to the territorialization of social relations and to the political implications stemming from their respective aesthetics regarding capital accumulation, topologies of domination, and class formation. Respectively, these are the axiomatic city-state, the poliorcetic vertex, ${ }^{5}$ and the aesthetic contado. However, before building these concepts into a coherent form, it is necessary to be clear on the strategic problematic in which this axiomatic city-state has emerged.

\section{2 | GLOBAL CITIES: BETWEEN WORLD-SYSTEM AND STATE-TERRITORY}

The problem that confronts us, both in general and in particular, is that of grasping the spatio-temporal emergence of particular state formations that connect state-territories to the capitalist world system at large and that situate the particularity of a state-territory within the social forces of the world system and its world history.

In terms of the spatio-structural transformation of the state-territory, Britain's post-colonial and post-industrial legacy has entailed a concentration of the processes and structures of capital accumulation in the metropole as alternative poles across the generality of the state-territory have become weakened and subordinated, and are now one with Nineveh and Tyre. As in other $21^{\text {st }}$ century core states of the capitalist world economy, the especially acute manifestation in the British case of new lines of cleavage within the state-territory has necessitated a radical concentration of apparatuses able "to monitor, contain, seize, and redistribute resources within national territories" (Tilly, 1994, p. 27), simultaneous to the apparent melting away of the national referent (Smith, 1998, p. 50-51):

We can think of these developments as constituting new geographies of centrality and marginality that cut across the old divide of poor/rich countries, and new geographies of marginality that have become increasingly evident not only in the less developed world but inside highly developed countries (Sassen, 2000, p. 85).

Behind these various divergences and convergences in our time lurk two colossal processes: globalization and the crisis of the democratic nation-state (Tonkiss, 2006, pp. 3-4, 56-61). Between these processes, where the most complex meanings of the global are being constituted (Sassen, 2006, p. 1), new forms of stratification, exclusion-inclusion, spatial reconfiguration, ideological legitimacy, lifestyle vergence and power relations, are emerging from the tensions and fissures. With the enduring role, therefore, of the territorial-state as the primary formal political structure through which these two great vectors are coming into dialectical relation with one another, this epochal transformation is resolutely "taking place inside the national [framework] to a far larger extent than is usually recognized" (Sassen, 2006, p. 1). The British nation-state is literally being pulled apart along the axes of these two world historic poles, but on a plateau of omnidirectional surfaces, with a resultant deterritorializing "disjuncture in governance" (Mittelman, 1996, p. 197), made manifest from the 1970s on and resulting in the neo-"liberal problem-space" in which we now live (Gordon, 1991, p. 16; Burchell, 1993). ${ }^{6}$ David Harvey has summarized this problematic in more precise geographical and regional terms: 
Regionality crystallizes according to its own logic out of the molecular processes of capital accumulation in space and time. In due course the regions thus formed come to play a crucial role in how the body politic of the state as a whole, defined solely according to some territorial logic, positions itself (Harvey, 2003, p. 105).

I argue that the global city of London, as a particularly potent urban assemblage in the world system, has emerged as strategic geo-social formation in response to the logic of accumulation and the logic of territory that inscribes a particular political idiom of command and control over and through that logic of accumulation. This is a matter of grasping particular theaters of planetary urbanization as one of the "operations of the global" (Stäheli, 2012, p. 233), which, of course, is not an attempt to represent the global as either a rhetorical strategy or a teleological scale (Stäheli, 2003), but rather it is an attempt to "think the operative dimension of relations" in the world system by situating them simultaneously in the "materialities and modalities" of that world system (Tellman, Opitz, \& Stäheli, 2012, pp. 210-213). This is a world system where "the hinterlands of major cities, metropolitan regions and urban-industrial corridors are being reconfigured as they are operationalized" in the metabolism of that world system (Brenner \& Schmid, 2017, p. 188). So how can we characterize this operationalization, and how can we comprehend the imperative that drives this operationalization?

Elsewhere (Welsh, 2017), I have argued that global cities have emerged, in the long-term conjoncture alluded to above, as strategic post-disciplinary devices in the accumulation dynamic of the world system. By placing global cities into the chronic contradictions of accumulation in world ecology, we can begin to see how rapid planetary urbanization is connected with the disparate phenomena of globalization in a way that begins to clarify how global cities such as London are implicated in the emplacement of global oligarchy as a strategic reaction to persistent and drawn out accumulation crisis across the core states of the world system. The "frontier inversion" of the world system that is characteristic of this conjoncture (Moore, 2015), and that is internalizing capitalist appropriation strategies and structures to the core states, can be understood as the global imperative according to which the axiomatic city-state is but one particular spatio-temporal response. The particularity of that response is a matter of historical legacy, political culture, geographical situation, and contingent strategic action in class formation. What follows is an exploration of this strategic response to world systemic crisis.

Three deficiencies in the theorizing on global cities and urban assemblages need to be addressed in terms of the spatio-temporal particularity of strategic response in the British case, and these deficiencies must be remedied through novel conceptualizations and innovative additions. The first is the insufficient grounding of emergent topographies of accumulation in the social metabolism of the world system in a way that brings out the new relation of the material and symbolic in the reproduction of capital. A number of scholars have pointed out that we need to integrate assemblage thinking with other critical traditions in global political economy, if we want not only to enrich its abstractions but to reinsert important structures into the increasingly ethereal conceptualizations of the urban assemblage, particularly in respect to the ontology of advanced or contemporary capitalism (Brenner, Madden, \& Wachsmuth, 2011; Farías, 2011; Wachsmuth, Madden, \& Brenner, 2011).

A second necessity is to resituate the territorial logic of power (Arrighi, 2010; Sassen, 2000) into a new relation with the logic of accumulation. This means discerning the contingent political action entailed in the emergence of global cities as a strategic response to the contradictions and crises of accumulation in the world system. While the necessity of accumulation conditions the parameters of action, a variety of strategic responses in the dialectic of contradiction offers space for contingent agency. The topography of the state-territory is constituted through strategic action, and even tactical action; it is not a given to be merely accepted. This makes a critical political geography of the state-territory an essential consideration for reformation in the dominant regime of political economy.

A third priority is to explore new relationships between urban assemblages and their various hinterlands. While global cities have been analyzed in terms of their internal dynamics (Sassen, 1991), as well as their relation to each other (Friedmann \& Wolff, 1982), much less consideration has been given to the effect of the emergence of the global city on the state-territories in which they are situated. This is hardly surprising, given the usual geographical and social location of global cities' research (that is, metropolitan elites who have little interest in exposing their dominion), but it 
is an exigency if we wish to think critically on the emergence of a metropolitan oligarchy and its crystallizing political geographies of social subordination, domination, and dispossession.

In light of these deficiencies, what can we say about the global city as the ligature and linchpin between the particularity of a state-territory and the generality of the world system? The spatio-temporality of the capitalist totality is in perpetual motion, shifting and displacing the flows of value around that totality through the sublative impetuous of dialectical relations that are realized locally. Rosa Luxemburg's (2003) limit point of internalization need never be reached, even in an utterly global capitalism, as retreat from an exhaustive capitalist contact in any given locale is entirely consistent with the ongoing momentum of the accumulation process as a totality. This is so even if it entails colossal destruction (Harvey, 2010a), anti-production (Guattari, 1984), frontier inversion (Moore, 2015), and accumulation reboot in any given theater of capital's empire (Meiksins-Wood, 2016, p. 131). In this manner, as an expanding and potentially contracting "ecological totality" (Harvey, 2010b, p. 196), capital can probably continue to function indefinitely (Harvey, 2015, p. 220). The emergence of our city-state in the neoliberal reconfiguration of the global capitalist order since the late-1970s constitutes an enabling socio-geographic structure, a servo of global capital, a spatio-temporal fix on the grandest scale accelerating through the tipping point, and has been derived to facilitate a strategic global displacement through the mechanisms of switching crises (Harvey, 2006, p. 428-429; 2010a, p. 93), and by a devastating retreat of capital at local and provincial levels at the threshold of transcendence (for provincial deindustrialization, see Sassen, 1991, pp. 8-9). This means that we ought to ruminate on the capacity of historical capitalism, as a set of relations and axioms of asymmetric flow and uneven development, to reinvent itself, shifting from place to place, reconfiguring space as it is canalized by it (Lefèbvre, 1976,1991), and thereby strategically defeating the moments of transcendence in capitalist social relations that are immanent to its logic. Asymmetric social relations in the global flow of capital are immanent to the ontology of historical capitalism, as without them there would be no motion, no accumulation, and thus no capital (value in motion).

This spatio-temporal dynamic, and its polar forces across multiple surfaces, is capitalist empire (Hardt \& Negri, 2000, 2005). It is the topological tracing of the command and control of the capitalist class onto the global regime of accumulation, and it is from the dialectical contradictions between the reproduction of the regime of accumulation and the material social metabolism that the axiomatic city-state formation is actualized in the world system as a geographically and historically particular state apparatus. These are the conditions in which the metropolitan positionalities of surplus value appropriation-poliorcetic assemblage-are established, and in which the new aesthetic of class subordination-aesthetic contado-is inscribed, as two complementary strategic components of the axiomatic city-state.

The morphing of $21^{\text {st }}$ century UK into a city-state represents, therefore one of the processes of denationalization; processes that are nevertheless "part of globalization even though they are localized in national, indeed subnational, settings" (Sassen, 2006, p. 2). We are dealing with intranational processes that are simultaneously "oriented towards global agendas and systems," while being "instantiations of the global, which are structured inside the national" (2006, pp. 2, 3). I believe the axiomatic city-state concept is an effective means of unpacking these processes and for getting to grips with "new types of global scalings of dynamics and institutions" in a way that does not "freeze the image of state territoriality into a generalized ontological feature of social life" (Brenner, 1999, p. 50; Sassen, 2006, p. 1), even if it does unavoidably offer a momentarily fixed tableau. What it does supply is a means for rethinking the city-state formation in historical capitalism.

The original historical discourse on the city-state is where any critical political analysis of this kind must simultaneously begin and depart. This is so if we wish to animate the critical politics of territoriality (Agnew, 2013; Brenner, 1998, 1999; Ruggie, 1993). Deployed as a historical ideal-type, there is a danger of the city-state concept pulling us back into the hated Cartesian state-centrism that rarefies space container-like or restricts us intellectually to the retrospection of purely historical regimes of capital accumulation (Agnew, 1994; Brenner, 1999, pp. 40, 46). It seems therefore imperative not so much to remove the state from analysis, which would be "a denial of the state's continued relevance as a major geographical locus of social power" (Brenner, 1999, p. 41), but to decenter and recharacterize it in terms of "an articulated concept of territory" (Elden, 2013, p. 9). My articulation of the axiomatic city-state is that of a particular historical and geographical configuration of the state apparatus of surplus value capture. ${ }^{7}$ It is one that allows us to 
escape the territorial trap of state-centrism that ensnares us between space as an ahistorical static platform of social action and "state territoriality as a preconstituted, naturalized, or unchanging scale of analysis" (Brenner, 1999, pp. 41, 45). It rather offers a way to approach the territorialization of positionalities of capture upon which urban oligarchy develops and prospers in the $21^{\text {st }}$ century conditions of capitalist empire.

I believe this maneuver is both justifiable and worthwhile because, as the epigram suggests, in the contemporary British experience the axiomatic city-state concept has clear intellectual valence as a heuristic device (Glassner, 2004, pp. 3, 6), or as rhetorical political weapon for rearticulating new terms of class struggle within the state. The concept has clear force as a "rhetorical pronouncement" (Agnew, 1997, p. 102). Additionally, it provides one of those summarizing concepts that Immanuel Wallerstein thought necessary not only for apprehending phenomena, but for creating knowledge upon which we can predicate our politics (1974, p. 415). The axiomatic city-state concept offers one of those mental conceptions by which we may realize the labor of programmatic action (Harvey, 2010b, p. 195; Marx, 1990, pp. 283-284). Thus, such an arguably reductivist procedure can be justified as part of an intellectually political move to generate "fundamentally interested knowledge" (Foucault, 2013, p. 227), so that we might meet the needs of a radically alternative way of governing our British population and ourselves in the world system of the near future. What is required is a concept that has the analytic, rhetorical, and didactic potency to draw together various strands of critical thinking into a politically relevant and striking argument for a new paradigm of thought-action in British politics that is constitutive of class struggle, rather than ethno-nationalist regression. It becomes a way to reconceive populism not in simple national terms, but in class terms, as with the city-states of ancient and early modern Europe, though articulated into the axiomatics of an advanced capitalist world system.

I offer the city-state concept, therefore, as a tool of my political analysis, not the beginning of a scientific statement. It is not an epistemic representation providing a scientific model, but a critical epistemic condition, a regulative idea that claims no ontological or explanatory exclusivity and simply aims to fashion a particular political discourse and critique. It is not a positive or utopian "image of the city" (Lynch, 1960), but a negative image intended to establish a critical object. Minimally, it is an attempt at a "discursive framing of spatiotemporal options," and a nudging of the "necessary horizons of the modern political imagination" towards a greater contingency of spatial limits (Agnew, 1997, p. 102; Walker, 1992, p. 6). Maximally, it is one of the "models of realization" of a worldwide axiomatic capitalism in the here and now that is immanent and excessive of form (Deleuze \& Guattari, 2013, p. 528).

The point of resuscitating the historical city-state resituated into the accumulation regime of capitalist empire today is therefore not to make a systematic comparative analysis, nor to offer an anachronistically "simple transposition of historical moulds" in the form of a timeless model, but rather to "let the knowledge of the past work on the experience of the present" (Foucault, 2010, pp. 130-131). Although new metaphors are needed for world politics, this is not a "simple reversal of a long-lost past" (Anderson, 1996, p. 150). However, historical familiarity with the tropes and structures of oligarchic city-state formations now imbricated into the dynamic of advanced capitalist social relations and axioms can help to stimulate some historically versatile yet fresh reimaginings of the relation of territoriality to the state (Anderson, 1996). But this is only if we are duly sensitive to geographical and historical particularity and emphatically do not deploy it as an ideal type (Friedmann \& Wolff, 1982, p. 313).

With this in mind, I nevertheless want politically to emphasize the historic city-state's practical and ideological commitment to the maintenance of privilege, recalling the aristocratic origins of the commune as a recurrent configuration of associated human habitation (Martines, 1980, p. 184). But establishing the city-state as a potent historical template for the political and social territorialization of privilege is merely a beginning. Lauro Martines argued rightly of the citystate that the problem is "to trace the workings of privilege, to unveil its covert forms and to see its ramifications," all the more so if we wish to attain a more contemporary understanding on the complex plateaux of advanced capitalism, but a conceptualization is a useful beginning. The historical city-state from which my thinking draws its critical energy is not then the Aristotelian city-state conceived as the horizon of the political and a recapitulated polis of the zōon politikón, nor is it strictly the early-modern city-state that famously obstructed the formation of territorial-fiscal states like Hobbes's "worm in the entrails". Rather it is a matter of the axiomatized and axialized city-state of advanced capitalism "for whom stasis is death" (Virilio, 2006, p. 40), and yet for which the necessary vertices of friction and deflection 
must be established to capture the flows of value in a supposedly smooth space of effortless capitalism sans frontières (Ohmae, 1990; Reich, 1992).

As the key conceptualization of this exploration, the axiomatic city-state is an attempt to coordinate the historical familiarity of the city-state concept-mobilizing all its historical semantic resonances of urban oligarchy, capital appropriation, social stratification, and class antagonism-with the contemporary context of an advanced capitalist world system that requires assemblages of fixity and flow. It is through the concept of the axiomatic city-state that I want to address a vital question emerging in regard to global cities: how to relate the world system through city assemblages to their various hinterlands. My response is built on the twin imperatives to accumulate (Marx) and to govern (Foucault); the logic of capital and the logic of territory.

\subsection{Concept 1: The axiomatic city-state}

So how has this axiomatic city-state formation arisen, what is the topology from which it draws its form, whence the social forces of transformation, and what is the dynamic motor through which its positionalities have been structured?

By my vectored and axial notion of the city-state as a convergent point of conjunction for flows, where the city becomes a stopover point on "the synoptic path of a trajectory" in the flow of capital (Virilio, 2006, p. 31), I treat the city in situ more as an assemblage than as either an aggregation of systems of fragmented sovereignty (Tilly, 1990, pp. 21, 25), or territories "reified as set or fixed units of sovereign space" (Agnew, 1994, p. 59). This means understanding that "territory is a political technology" (Elden, 2013, p. 14), in which positionalities are established, not in spatially extensive terms of location, but in terms of relationality. It means thinking about the British polity not as a spatially extensive surface of absolute space contained by a littoral boundary and governed through the intervention into that space by a sovereign authority, but rather as an aggregation of social relations between people inscribed into and realized through the material medium of their relative position in "relational space" (Lefèbvre, 1991). The matrix of these social relations mediated through topographical position is territory and as the density of these social relations intensifies with proximity to the metropole an assemblage begins to form. This is the axiomatic city-state of advanced capitalism.

As can be seen, this rethinking of territory and territorialization is an attempt to depart from the ontology of planer extension, beholden as it is to entrenched mapping bogged down in the dimensional geometric terminology of levels, spheres, layers, and radii, and a scalar continuum from the individual through the national to the global, along which we seem to move back and forth arbitrarily or paradigmatically at our scholarly leisure. The spatial, axial, and relational complexities of the global city are immense, so we must get away from such mental conceptions of the city as a "radius of an imaginary circle" (Tilly, 1986, p. 306), according to which either the capital is bounded by the courtines ${ }^{8}$ of the M25 or it is extended into a post-industrial south-east "city-region" (Brenner, 1998, p. 23). The notion of a qualitatively specific and discrete city, and therefore by implication its putative hinterland, is profoundly questionable in a milieu of rapid planetary urbanization where even spaces that lie well beyond traditional city cores and suburban peripheries have become integral parts of a worldwide urban fabric. This means that "the urban can no longer be understood with reference to a particular 'type' of settlement space, whether defined as a city, a city-region, a metropolis, a metropolitan region, a megalopolis, an edge city, or otherwise" (Brenner \& Schmid, 2017, pp. 186-189), but must entail a new conception of the reach of social relations.

This is especially important to bear in mind if we take urbanization as a process (Harvey, 1996), and if we perceive the capitalist world system as one constituted by spaces of flows as well as by spaces of place (Ruggie, 1993, p. 172). The dromology of the axiomatic city-state, ${ }^{9}$ the progressive annihilation of space through time in historical capitalism (Harvey, 2010b, p. 206), destroys any scalar delimitation of the city (or indeed the state) and necessitates a more imaginative dimensionality. The negation of space as the reduction of distances has become a strategic reality (Virilio, 2006, p. 149). Thus, Charles Tilly's cartographic "monochromas that represent more or less continuous sovereignty over extensive territories" (Tilly, 1986, p. 301) threaten to bind us to the homogeneous planer extensio of the territorial state with an immanent center and divisible homologous parts (Deleuze \& Guattari, 2013, p. 453), and imprison us intellectually in "homogeneous blocks of territorial space" (Agnew, 1996, p. 1929). The apparent obviousness of a 
circumferential littoral to the state-territory in the British case simply reinforces this fetish. The potential implication of a territorial way of thinking is that we can entertain a view of citizenship understood in terms of an aesthetic relation to something in a space of flows, rather than as a location on a spatially delimited surface. To map such a territorial citizenship should become a major preoccupation in our new political geography.

Regarding the formation of global cities, it is not so much that "the processes that accumulate and concentrate capital also produce cities" (Tilly, 1990, p. 17), but that the city is that process of accumulation as an assemblage, a "constellation of singularities and traits deducted from the flow-selected, organized, stratified-in such a way as to converge" at and through the assemblage (Deleuze \& Guattari, 2013, p. 473). The assemblage is also therefore as architectural, or geological, as it is fluvial. It is necessarily of a minimally fixed degree of physicality to satisfy the needs of capital to reproduce through time, and it is the intensified points of deflections that afford the "geographical embeddedness of capital" that makes it "place sticky" (Sassen, 2001; Yeung, 1998, pp. 293, 299), even in the supposedly borderless and frictionless idiom of finance (Ohmae, 1990). It is true that we need to get past that "bias of our conceptual equipment in favor of the space-of-places," and which prejudices us "against the space-of flows of capital that defines the process of capital accumulation" in the hyperspace of capital (Arrighi, 2010, pp. 81, 85; Ruggie, 1993, p. 172). However, capital accumulation historically has developed simultaneously in both spaces. The axiomatic city-state concept contributes to a reassessment of the territorial relation between both in the contemporary British particularity by integrating into a political geography those semiotic modulations that animate the emplaced materiality of the British state in the idiom of financialization.

The more particular problem that we then have is to redefine how territoriality has changed regarding the global city, and regarding the matrices of social relations from which it is constituted. The neoliberal view of the city since the 1980s has been that of the multicultural melting pot that doubles as a great productivist engine of prosperity. It is the utopianism of Mandeville's Fable of the Bees (1724/1989), alloyed to Jane Jacobs's encomia to the city (1970, 1985), in which the life of the mercantile city is rejuvenated and energetic prosperity is unleashed by breaking down enframing and overbearing structures of constraint both in relations between people and in their conceptualizations. The upshot of this celebratory discourse is that vicious chaos is virtuous prosperity, and that to apply democratic controls through thoughtful scrutiny and concerted action in the name of whatever category (nation, class, or the people) is to retard, contain, and overcode to our collective impoverishment. The message is simple: if we interfere with the metropolitan oligarchy they will bankrupt us or take their dazzling qualities elsewhere. Geopolitically, the city must therefore become free, autonomous, and unconstrained from any territory in which it might be situated and independent of any sovereign power exercised from it, if it is to prosper. However, the city is its relations, and those relations are entirely positive in the Nietzschean sense. In the necessary asymmetry of capitalist social relations, unconstraint at one end means subordination at the other. Over the last three decades during which this has been taking place through the disjuncture in governance outlined above, an international metropolitan elite has emerged from within the metropolitan center with interests, experiences, and horizons antithetical to the national referent and culturally and ideologically autonomous from the state-territory as a whole.

The problem, therefore, with the Mandevillean tableau, and thus with the self-satisfied liberal ideology of the city that it inspires, is that it offers consideration only of the moment of deterritorialization and nothing of the reterritorialization that necessarily coexists with it (Deleuze \& Guattari, 2013). The result is to overemphasize the decodified energy released by the "grumbling hive" from those codified structures of constraint and sclerosis that Mandeville claimed of the early modern mercantilist, seigniorial, feudal, or ecclesiastical city, and that liberals now claim of the national social referent and its economically illiterate and politically incorrect constituents. The consequence today is to ignore the axiomatic moment of recodification actualized since the $1980 \mathrm{~s}$, and it is by consideration of this very thing via the axiomatic city-state conceptual brace that the appropriative apparatus of the metropolitan oligarchy and its retainers can be identified regardless of the celebratory neoliberal bromides asserted about the metropole.

The neoliberal police science of the British state has been tasked with enforcing the territorialization of the neoliberal city since the 1980s. This has meant striating the global city's interior space to establish a new territorial constellation of positionalities over the flow of capital. This reterritorializing capture of flows in value has been at the heart of the successive topological complications and displacements in the government of a "liberal problem-space" over the 
last four decades of British political history (Gordon, p. 1991, p. 16). All is subordinate to the survival and strengthening of the state apparatus, regardless of content or character, for it is its political reason (Foucault, 2002).

The historical and geographical particularity in the state apparatus's content and character may be motivated and influenced by the changing global regime of accumulation in capitalist empire, but politically contingent struggle is decisive. Through this, a new territoriality is established for the state apparatus. It is by mapping this new territoriality that we can grasp the new political aesthetics of the British city-state, and thus come to understand how we have become ruled not by the home-grown heroes of capitalist production, as we have been told, but by the transnational warriors of capture and appropriation, in whose interest any further deterritorialization of the neoliberal city-state must be held in abeyance at all costs.

My presentation of the aesthetic components that are constitutive of the axiomatic city-state is broken down into the poliorcetic vertex and the aesthetic contado. Simply, these sub-concepts of the axiomatic city-state refer to the formations of domination and subordination, respectively, in the reterritorialization of class power that is realized through the reconfigurations of the axiomatic city-state. These seemingly esoteric terms are actually fairly simple, but are necessarily named in this way in order simultaneously to situate them in a historical discourse of city-state formation, to draw semantic connections from certain post-structuralist lines of theorizing (Virilio, Rancière, Deleuze-Guattari), and to render them apposite for the hyper-semiotic idiom of advanced capitalism.

\subsection{Concept 2: The poliorcetic vertex}

Behind the analysis and argument below lies a key claim regarding the changing logic of political economy in the capitalist world system. The expanding frontier of commodification in the world system, as discussed variously by Federici (2004), Luxemburg (2003), Marx (1993), and Mies (1986), is becoming mired in crises of continued capital accumulation brought about by strategic contradictions in the totality of capitalist social relations (Moore, 2015). The result is a zero-sum political economy in the capitalist core states (Hornborg, 2001, 2009), whereby accumulation must continue but it must be accumulation through techniques of absolute surplus value extraction, rather than the more socially acceptable extraction of relative surplus value. The exploitation of labor through productive processes in an expanding reproduction of the totality of capitalist relations is therefore making way for an increase in redistributive dispossession (Bin, 2018, p. 80) realized in apparatuses of capital appropriation.

If the totality of capitalist social relations can no longer expand at its historical frontiers, then new local frontiers must be created internal to the core of that world system. This means that an inversion of the frontier of capitalization is becoming manifest in the world system as frontiers of capitalization are being inscribed in the core states themselves (Moore, 2015). As dominant elites struggle to construct positionalities of surplus extraction, as the predicate for the actual accumulation of capital through commodity exchange, new territorialities of capital accumulation emerge on the political topography of the world system along with new constellations of social relations of political domination. The axiomatic city-state is one such territorialized constellation.

Therefore, as in other historical and geographical instances of strategic appropriation, urban oligarchies in such circumstances evince a marked tendency toward a predication of their political and economic power on position over capital flows, rather than on leadership and the orchestration of production (Arrighi, 2010; Harvey, 2013; Martines, 1980; Meiksins-Wood, 2003). It is the consideration of this that is lacking in contemporary representations of British political economy, dominated as they are by neoclassical political economy and its hegemonic liberal ideology of the city. There is also a lack of recognition of this political economy in thinking on urban assemblages, as indicated earlier.

I propose the term poliorcetic vertex as a more effective way to conceptualize the formation and reproduction of the positionalities of surplus appropriation that sustains metropolitan oligarchy. Derived from Greek, poliorcetics $(\pi \mathrm{o} \lambda \iota \mathrm{o} \rho \kappa \eta \tau \imath \kappa \alpha)$ is concerned with the techniques, forms, strategies, science, or art of fortification and siege warfare. A vertex is simply a point at which either a number of vectors converge or a point at which a vector deflects or deviates from a trajectory. Taken together, the concept of the poliorcetic vertex therefore denotes a semiotic yet material positionality established at a point or surface of deflection in the flow of capital, a figurative glacis or a convergence point that must be maintained and defended amidst antagonistic forces (Virilio, 2006). Ironically, though 
it is quite abstract, this innovation is essential in order territorially to ground the urban assemblage into the material social metabolism, so as to enable the exposure of the positionalities of capture that sustain an urban oligarchy through time over the vectored capital that flows through the urban assemblage. Social poliorcetics concerns the establishment of social relations that are fixed to a sufficient degree by proprietorial control over the relational positionality, which are then defended, and which can be achieved by physical, semiotic or symbolic, legal, discursive, or other cultural and ideological means. It is in the establishment of this patrimonial control that the subtle political agency of metropolitan elites is made manifest for what it is: more the martial seizure of social position by a neofeudal aristocracy than the productive activity of a hyper-bourgeois "creative class" (Florida, 2005; Graham, 2010, p. 47).

The productivist apologetics in the liberal city mistakes effect for cause, form for substance, signifier for signified, and revenue for wealth. This view fails properly to perceive the state apparatus of the axiomatic city-state, not as the producer but as the converter and capturer of the value in motion that is vectored through it (Deleuze \& Guattari, 2013, p. 451). Capitalists large and small do indeed "occupy the realm of exploitation, where the relations of production and exchange themselves yield surpluses, and capitalists capture them" (Tilly, 1990, p. 17). However, whilst the heroic capitalist exploits at the moment of production, the capturer appropriates from the flow of value by deflection in the medium of social relations, that is, by their positionality on/in the territory of the axiomatic city-state. The exploiter and appropriator are two distinct roles or bearers of relations (Träger), though sometimes unified practically in a single person. What we take to be productive activity in the reproductive activities of a metropolitan elite is then rather the topographic realization of value produced elsewhere, or elsewhen, and by others.

The point here is that the value flowing through this aggregation of positionalities of capture is overwhelmingly produced elsewhere in the capitalist world system through laboring activity in nature, even if the matrices of the flow of value are commanded from the strategic vertices of the core states of capitalist empire. It is this feature of the axiomatic city-state reconfiguration that reduces the rest of the state-territory to the same status as the most far flung regions of the formal empire of yore.

This constitutive activity is a frenetic and competitive construction of positionalities of capture (appropriation) in aggregation that make up the establishment of the poliorcetic vertex as a grand strategic assemblage of capital accumulation in the state apparatus set into the spatio-temporal imperative motions of historical capitalism. The non-productive activity of capture consists in acquiring patrimonial control over the momentary points of convergence in the global flows of capital (value in motion) that converge on the metropolitan assemblage. This means that territory is not really a juridico-political notion, as has been claimed (Elden, 2013, p. 7; Foucault, 1980, p. 68), for, as with nine-tenths of the law, patrimonial control is more a matter of de facto possession than de jure property. Just consider the scramble for educational credentials in institutions increasingly concentrated around the metropole, think about the access to media projection located exclusively in the London circle, reflect upon the subtle and radiating insinuation of metropolitan speech patterns across the state-territory in place of received pronunciation that mark a person as a metropolitan insider, and of course, note the plutocratic reproduction secured by soaring house prices that act to purge politically aspirational citizens from proximity to all these advantageous positionalities.

In the $21^{\text {st }}$ century tripartite division of labor, introduced by Robert Reich (1992, pp. 174-180), symbolic analysts are set apart from the routine production servers (wage slaves) and in-person servers (domestics) over whom they rule. As semiotic manipulators and engineers of the poliorcetic vertex, they are not the heroes of production but the "warriors of capture" (Deleuze \& Guattari, 2013). They are not merely bankers, financiers, lawyers, property "developers," media moguls, or politicians, but anyone capable of establishing control over monopoly rent-seeking positions. In this way the austerity regime opens itself up to a variety of immanent critiques: not only is the austerity of the provincial populations at odds with the waste and conspicuous consumption of an over-capitalized metropole, but this capital is not deployed in domestic rounds of production, but is either consumed away (destroyed) or spirited away (capital flight). So much for the powerhouse of the UK economy. Where does this leave the rest of the citizenry? 


\subsection{Concept 3: aesthetic contado}

The aesthetic contado offers us a way of understanding not only how class is generated from relations of domination, dispossession, exploitation, and appropriation, but how reconfigurations and reterritorialization of these relations generate new isomorphic lines of class. In brief political terms, the former state-territory of the UK (and beyond) has become a "vast camp" and "hinterland in which activity [is] on the decline" (Virilio, 2006, p. 40). If the political structures of the capitalist state must preserve a sense of spatial integrity, and this cannot be in the name of national identity, it must be that of some kind of territoriality (Walker, 1992, p. 11). It is in this territoriality that a post-industrial and post-disciplinary notion of class can be conjured from the social aesthetics of subordination.

In the sociological understanding, class is assumed as a categorical entity, a grouped unit, an object of more or less clearly delimited coherence and discreteness. It is something that can be rendered into statistical form, tabulated, and studied as a thing. In this view, class is a socioeconomic stratum of society, it is an identity group, it is the basis for organization, it is something of which one is a member. This makes it a conceptualization that is congenial to the extensive notions of space. However, in the idiom of political economy, class is something relational. In the historical materialist tradition of political economy in particular, it is a social relation generated by the mode of production; in our case, a capitalist mode of production. More precisely, and despite the tremendous range of intellectual positions on this, class is the experience of the social relation of exploitation/appropriation contrived through various techniques. In this understanding, the key determinant of class is a "common shared element" in how the aesthetic relations of capitalist society are experienced (Hardt \& Negri, 2005, p. 100). Put another way, it is the set of common experience and common interests in being exploited, appropriated, or dispossessed (Meiksins-Wood, 2016, p. 91), and it is a way of approaching class that conjuncts the changing topology of the state-territory to changes in the material social metabolism through the conceptual shift to territory. How does this political economic approach to class map onto the new cartography of the British state?

The boundaries of regions of this sort are always fuzzy and porous, yet the interlocking flows within the territory produce enough structured coherence to mark the geographical area off as somehow distinctive relative to all other areas within a national economy or beyond. Structured coherence usually extends well beyond pure economic exchanges, fundamental though these may be, for it typically encompasses attitudes, cultural values, beliefs, and even religious and political affiliations among both capitalists and those whom they employ. (Harvey, 2003, p. 102)

The first implication of abandoning spatial extension is that the state-territory ending at the coastline that marks off the geographical area must be abandoned and a more complex and abstract, though no less material, notion of territory be again explored. The advanced communications technologies implicated in our contemporary social relations are also important in rendering these social relations both more complex and more difficult to locate. If we shift our understanding of the British polity away from a spatial container in which we are all equally citizens of the state, and instead move toward a complex of territorialized social relations in which our individual positionalities in this complex are fundamentally asymmetric and oriented to the intensities of the metropolitan assemblage of the axiomatic citystate formation, then a different picture emerges. Now we have an understanding of citizenship, not in the Hobbesian universal and equal subordination of all to the state in a given spatial jurisdiction of sovereign power, but a highly variable, uneven, and asymmetric topography of axial social relations increasingly poliorcetic as they converge upon the intensities of the metropolitan assemblage. What then emerges from the common aesthetic and daily experience that individuals have of this formation is a non-exhaustive class phenomenon. What was hitherto a uniform national membership (nationality), or membership of a category determined by lines of identity and difference (sociological class), now becomes a stratified and differential experience of being generated as a class through the establishment of social relations, that is to say, the experience common to a (large) social fraction of being subordinated to a metropole in varying degrees by a complex set of techniques and apparatuses of exploitation, appropriation, or dispossession. This new, admittedly variable and uneven, relation of the state-territory to the city-assemblage lays the intellectual foundations 
for our new social class-citizenship of this city-state in territorial terms beyond the bounded and exclusive absolute space of the UK.

The usual metaphor deployed historically when discussing the immediate geographical plane of extraction from which the stratum of the city-state is established by the state apparatus for the purposes of capture of global capital flows, is the "hinterland". However, this betrays an overly mercurial way of thinking that is too redolent of the Hansa and the benign merchant of Kant's perpetual peace, ${ }^{10}$ by which that planer extension is understood simply as source of materials and labor, and a destination market for exotic commodity chains via the metropolitan entrepôt. In the semiotic idiom of finance, with its emphasis on command and control, and in the relational topography of the axiomatic city-state, this planer expression seems inadequate. Instead, the relation of social positionalities connecting the stateterritory as a whole to the metropolitan power, is more pertinently summed up by the term contado, along with all its more germane historical connotations of coercion, tribute, and muster, in a state-territory subjected to chronic appropriation.

Conventionally, the contado is that terrain in relation to a city over which the latter's sovereign juridical and coercive power is exercised, typically over a "consolidated national enclosure" in the modern context (Bratton, 2006, p. 11). But this is insufficient. As the nation-state disintegrates imperfectly, incompletely, and asymmetrically to a territorialstate, a structural antagonistic synthesis within the state is revealed that formalizes in a contextually particular way the "capitalized-coercion paths of state transformation" regarding social formations with dominant cities (Tilly, 1994, p. 12). This is what we have seen in the British political narrative since the neoliberal counterrevolution destroyed the national industrial base, dismantled the public spaces of the provinces within, and redefined the political "we" along sectional, class, or other lines (Agnew, 2005, p. 444). Tilly's "well-defined, continuous territory" of the state is problematized (1994, p. 4), and reconfigured from a spatio-planer extension and referential imaginary into a strategic and membranous ambiguity of city and integrated contado, over which the former maintains more than a vulgar juridico-structural sovereignty,and is in accord with a relational dimensionality more complex than the "simple legalistic map of state sovereignty" (Walker, 1992, p. 46). The contado is a way to grasp the dialectical relation of territory and assemblage in the sovereignty regime of the axiomatic city-state formation (Agnew, 2005, p. 438), but it is just as much the sovereign logic of capitalist empire, as it is any juridico-political monopoly over coercive authority, and this logic is inscribed into the territory in an aesthetic structure appropriate to a capitalist idiom of constantly internalized contradictions.

What is vital to the political economy of the axiomatic city-state is that its citizens occupy James Anderson's position of "antagonistic synthesis" (1996) that they are within reach of the metropolitan assemblage but are simultaneously denied access to its privileged positionalities of capture and command over capital (value in motion). Without it there would be no capitalistic state. On the one hand, the "making of spatial exclusivity is vital to the incorporation of social practices under state regulation" (Agnew, 1994, p. 71), and the motion toward privatizations and enclosures canalizes affects and consigns spatially in a closing syntax of control. On the other hand, and at the same time, without inclusion there would be no extraction of surplus value, no condensation or rationalization of value back to the social metabolism through command over labor power. The fixities of the poliorcetic vertex require defense, repair, manning by a retinue of modern squires, substitutes, and prostitutes. The penumbra of inclusion-exclusion is essential to the contado's territoriality, constituting a kind of aesthetic threshold to capital's flow, and city-state formations have proven time and again to be a historically effective and versatile topological device for realizing this antagonistic synthesis in the aesthetics of political economy.

This presentation makes us ask, rather than the spatially extensive question of our coordinates or location in a delimited space or imagined community of extension (i.e., the UK), what might be the territorialization, coding, and affective quality of the relation one has to the positionalities of exploitation and appropriation that make up the metropolitan assemblage through which the sovereign logic of capital is rendered into a political strategy constituting those in the provinces as contadini, regardless of any formal national citizenship or ethnos conventionally understood. It also redefines the problem of class organization by shifting emphasis from fetishized units of categorical identity to isomorphic lines of aesthetic experience, opening up conditions of possibility for new configurations of class organization pertinent to the new topographical configurations of power relations in the post-disciplinary state-territory. 
In this way, we can also start to rethink the historical subject of struggle in the mode of production that has been fractured, dispersed, and disorganized across the core states in the evanescence of Fordism, Keynesianism, welfare state capitalism, and industrialism, and overtaken by the "end of work" (Amin, 1995; Görz, 2012; Offe, 1985; Sabel \& Piore, 1984). While the factory in its broadest sense as an armature of disciplinary power no longer constitutes the principal technology of dispossession and control in the mode of production (Deleuze, 1992), we must search for expressions of the "social factory" (Negri, 1992), in order to perceive once again the operational aesthetic of capitalist dispossession, and so to anticipate the classes that this aesthetic will always generate anew in historical capitalism. If the poliorcetic vertex as metropolis is a likely formation through which the social factory is to be orchestrated and coordinated (Negri, 2018), then the aesthetic contado expresses the manner in which class is generated in the new idiom and indicates how the problem of organization can be reformulated and revitalized, and grasped by the horns.

\section{CONCLUSION}

It is actually very difficult to give a tangible or systematic presentation, let alone empirical details, of this axiomatic citystate in a way that will satisfy the need for clarity amongst many social scientists. The purpose of this article is not to offer models to be applied, but to begin a process of "adventurous, experimental and boundary-exploding" reconceptualization that can then "facilitate empirical investigation and visualization" in subsequent analyses (Brenner \& Schmid, 2017, p. 190). Therefore, it is through a critical distancing from the conventional ways of looking at global cities that a sense of the London-UK assemblage can emerge, rather than through the explicit exposition of empirical relations or positionalities on my part. My intention here is to get others to think through what they observe via the conceptualizations I have attempted to formulate in this piece. By giving too much empirical detail and offering too much content either to the concepts or the assemblage itself, this aim can easily become obscured and distracted by objections potentially aroused by those empirical exempla (for some empirical examples, see Welsh, 2017).

The purpose of my argument is rather to show how it is by thinking through the axiomatic city-state concept, especially in territorial rather than extensive spatial terms, what appears as national or ethnic politics can more easily be seen as a form of class politics. Our city-state is built on the twin pillars of the positionalities of capture and the aesthetic creation of subordinate class experiences, and the relations of domination that are generated from them.

What is to be done? A number of political directions are open to us. We can begin by understanding the variously anti-metropolitan, anti-internationalist, and anti-establishment politics of populist nationalism implicit in recent events as being phylogenetically related to the classic urban and provincial movements of struggle one historically finds in city-state formations. This move initially seems quite implausible, for how can a state-territory of tens of millions be likened to a historical city-state that never broke beyond the limits of tens of thousands. However, the technological developments of the $20^{\text {th }}$ century-media and telecoms revolutions-provide a set of semiotic ligatures that transcend the physically geographical contours of the urban formation within which historical city-state assemblages have been limited. The axiomatic city-state is doubtless an abstract concept, but one that is "abstract yet real; ideal yet effective; absolute yet 'differentiated'" (Deleuze \& Guattari, 2013, p. 255).

I argue that with appropriate reconceptualization for the terrain of advanced capitalism, the city-state can be resurfaced rhizomatically as an inspiration for redefining movements of political struggle. In provincial and metropolitan terms, these movements conventionally attempt to redefine the relations internal to the state-territory from those of an "autonomous metropole" to a "bargaining metropole" (Blockmans, 1994, p. 233), normally through the attempt to "introduce an overarching ideology, calling for an emotional identification by their subjects" (Blockmans, 1994, p. 242). The problem with the populist nationalist articulation of this politics is that it cleaves to the container of a national referent and thus continues to labor against historical social forces, the contradictions of which will become more, and not less, apparent. The jingoistic mobilization of one-nation Britain and the railing of UKIP ideologues might very well appeal to an increasingly illusive national referent, but such a politics remains merely the mobilization of a community of will and not a community of interest, and it will run afoul of the material contradictions in the British state which it glosses over with such apparent naivety. 
An alternative social-democratic articulation is favored by neo-Keynesians-the reformist confiscation (appropriation) of rent and the redistribution of surplus in the name of the generality (Lazzarato, 2015, p. 32). But this maneuver of decapitation is surely also compromised by the crumbling of the national-social referent, upon which the historically exceptional post-war social-democratic epoch was legitimated and energized. Likewise, it is also compromised historically by social forces that militate against its realization outside the fertile soil of the post-war era. In the axiomatic city-state, positioned precariously amidst the flows of capital in the world system, there are no dirigible commanding heights to be seized, the hydra-like assemblage has many heads, and the awesome capitalist powers summoned from across the empire of capital are likely to be insuperable (just think of the 1976 IMF loan stipulations forced on the Callaghan government, the coordinations of the European Central Bank, or the powers of News Corp and the US Treasury). It is also stuck in the planer spatial imaginary of extension, and the container of a societal referent.

The most promising strategy also happens to be the most radical. It is to undertake a new struggle over axioms and militate intranationally toward a rearticulated class consciousness in Britain, and not retreat into ethnonationalism or social-democratic nostalgia. The contado of the city-state constitutes the terrain of our subordinated positionality in the city-state; it is our new citizenship, and it produces the cunning ambiguity of our existential inclusive-exclusion in a new topology of political domination facilitating capital accumulation (Agamben, 1998). It is to lay siege to the fortified metropolitan positionalities of capture and monopoly rent in the city-state that we must bend our energies, if we wish to deconstruct, derail, and deterritorialize the sovereign logic of capital terraforming our state. This is a struggle over surplus capital (Harvey, 2010a, p. 228), entailing an assault upon the vertices of capture tactically, and upon the city-state assemblage strategically. But such a struggle will not simplistically pit the superannuated state-territory against the regnant city. Rather, it must draw on a class politics of struggle by the contadini across the city-state's topography of asymmetric relations in toto, rather than fall back on ethno-nationalist strategies or classic anti-urban reactions. The reterritorializations of the neoliberal global city must be deterritorialized once more, and a new counter-hegemonic war machine released across the state-territory (Deleuze \& Guattari, 2013, p. 487). This is, of course, what we are beginning to see in the events referenced at the outset. In this assemblage, if "it takes a network to fight a network" (Hardt \& Negri, 2005 , p. 58), then it also takes counter-engineers to lay siege to its poliorcetic emplacements. Assemblage thinking has devoted much energy to strategizing the former (Hardt \& Negri, 2017); now it must add the latter to its arsenal.

Many fear the anti-establishment and anti-metropolitan politics of Scottish National Party, UKIP, and other groups on the British state-territory. I suspect that populism need not be feared, but it must be engaged. It must certainly not be dismissed (Müller, 2016). The reflections of Raymond Williams on the challenges that recur for the Left have once again become highly apposite (Williams, 1976, pp. 86-87), for whom, as for us today, "the political geography as well as the political sociology of Britain needed quite new kinds of exploration". It is essential that we break out of the elitist tone so prevalent today in metropolitan intellectual circles, which has been so favored by English progressives from at least as far back as the Bloomsbury group, that theorizes "in contempt of people, of their hopelessly corrupted state, of their vulgarity and credulity by comparison with an educated minority". The strategic reappropriation of populist discourses - that is to say, the "mobilization of the existing resources of 'the people' against a naïve or alien ruling class"-is neither wishful thinking nor reactionary error. It is rather a matter of evading ahistorical and pseudoprogressive political thought. It is to be remembered that "most 'Marxist' movements ... grew out of and inherited and often depended on radical movements of other kinds," and that "the relation between 'class' and 'nation' ('people') proved to be exceptionally complex" (Williams, 1976, p. 86) in the historical praxis of anti-capitalist struggles. The exordium is clear and simple:

To stay with the existing resources; to learn and perhaps to teach new resources; to live the contradictions and the options under pressure so that instead of denunciation or writing off there was a chance of understanding them and tipping them the other way: if these things were populism, then it is as well that the British Left, including most Marxists, stayed with it. (Williams, 1976, p. 87) 


\section{NOTES}

${ }^{1}$ A capitalist axiomatic is "a social machine of control and capture," the axioms of which are not "theoretical propositions" but the "operative statements that constitute the semiological form of capital and that enter as component parts into assemblages of production, circulation, and consumption" (Lazzarato, 2015, pp. 147-148; Deleuze \& Guattari, 2013, p. 537).

${ }^{2}$ It is this liberal metropolitan social elite that most likely voted to remain in the EU on cosmopolitan-internationalist grounds in the central regions of Greater London.

${ }^{3}$ A conjoncture can be understood as a medium-term trend, a "connection between diverse but simultaneous phenomena," and can be contrasted with the structure of the longue durée (see Burke, 1990, pp. 112-113).

4 The term contado ('county' in Italian) originates in the Latinate comitatus and alludes to the relatively proximate lands that lie under the power of an urban centre. Those residing on this land and subjected to this power are contadini.

${ }^{5}$ The meaning of this term will become apparent below.

${ }^{6}$ Such disjunctures include widening income differentials, class ossifications, divergence of metropolitan and provincial social experiences, divergent housing requirements between classes and generations and the iniquitous distribution of the austerity burden.

${ }^{7}$ The state apparatus is that "whole regime of arborescent conjunctions" in the waterworks of a "hydraulic science of government" (Deleuze \& Guattari, 2013, pp. 484, 423), making of the city-state between fixity and fluidity at once one of the "great immobile machines," and a "dynamic vehicular landscape" (Virilio, 2006, p. 31).

${ }^{8}$ Courtine ('curtain') is a Latinate French term derived from the vocabulary of fortification, and describes an entailing, circumferential wall.

${ }^{9}$ The problem of relating time and space through speed (see Virilio, 2006).

10 The Hansa was a league of city-states in the Baltic and North Sea that dominated European trade from the $13^{\text {th }}-15^{\text {th }}$ centuries.

\section{REFERENCES}

Agamben, G. (1998). Homo sacer: Sovereign power and bare life. Stanford, CA: Stanford University Press.

Agnew, J. (1994). The territorial trap: The geographical assumptions of international relations theory. Review of International Political Economy, 1, 53-80.

Agnew, J. (1996). Spacelessness verses timeless space in state-centred social science. Environment and Panning A, 28, 1929-1932.

Agnew, J. (1997). The dramaturgy of horizons: Geographical scale in the "reconstruction of Italy" by the new Italian parties. Political Geography, 16, 99-121.

Agnew, J. (2005). Sovereignty regime: Territoriality and state authority in contemporary world politics. Annals of the Association of American Geographers, 95, 437-461.

Agnew, J. (2013). Territory, politics, governance. Territory, Politics, Governance, 1, 1-4.

Amin, A., (Ed.), (1995). Post-Fordism: A reader. Hoboken, NJ: Blackwell.

Anderson, J. (1996). The shifting stage of politics: New medieval and post-modern territorialities. Environment and Planning D, 14, 133-155.

Anderson, P. (2013). Passages from antiquity and feudalism. New York: Verso.

Arboleda, M. (2017). Preface. In N., Brenner (Ed.), Critique of urbanization: Selected essays (pp. 9-13). Basel: Birkhäuser Verlag.

Arrighi, G. (2010). The long twentieth century: Money, power, and the origins of our times. New York: Verso.

Bin, D. (2018). So-called accumulation by dispossession. Critical Sociology, 44, 75-88.

Blockmans, W. P. (1994). Voracious states and obstructing cities. In C. Tilly \& W. P. Blockmans (Eds.), Cities and the rise of states in Europe, $A D 1000$ to 1800 (pp. 218-250). Boulder, CO: Westview Press.

Bratton, B. H. (2006). Introduction: Logistics of habitable circulation. In P. Virilio. Speed and politics, 7-25). Los Angeles: Semiotext(e).

Brenner, N. (1998). Global cities, Glocal state: Global city formation and state territorial restructuring in contemporary Europe. Review of International Political Economy, 5, 1-37.

Brenner, N. (1999). Beyond state-centrism? Space, territoriality, and geographical scale in globalization studies. Theory and Society, 28, 39-78. 
Brenner, N. (2017a). The problematique of critique. In N. Brenner (Ed.), Critique of urbanization: Selected essays (pp. 16-24). Basel: Birkhäuser Verlag.

Brenner, N. (2017b). The hinterland, urbanized? In N. Brenner (Ed.), Critique of urbanization: Selected Essays (pp. 212-223). Basel: Birkhäuser Verlag.

Brenner, N. (2017c). Introducing the urban theory lab. In N. Brenner (Ed.), Critique of urbanization: Selected essays (pp. 261-267). Basel: Birkhäuser Verlag.

Brenner, N., \& Schmid, C. (2015). Towards a new epistemology of the urban. City, 19, 151-182.

Brenner, N., \& Schmid, C. (2017). Planetary urbanization. In N. Brenner (Ed.), Critique of urbanization: Selected essays (pp. 186191). Basel: Birkhäuser Verlag.

Brenner, N., Madden, D., \& Wachsmuth, D. (2011). Assemblage urbanism and the challenges of critical urban theory. City, 15, 225-240.

Burchell, G. (1993). Liberal government and techniques of the self. Economy \& Society, 22, 267-282.

Burke, P. (1990). The French historical revolution: The Annales School, 1929-89. Stanford, CA: Stanford University Press.

Deleuze, G. (1992). Postscript on the societies of control. October, 59, 3-7.

Deleuze, G., \& Guattari, F. (2013). A thousand plateaus. London: Bloomsbury.

Elden, S. (2013). How should we do the history of territory? Territory, Politics, Governance, 1, 5-20.

Elliott, L. (2011). Can the Coalition revive regional Britain while the City still rules the economy? The Guardian, 13 June.

Elliott, L. (2013). UK growth? Make London independent to mend the north-south divide. The Guardian, 22 September.

Ertürk, I., Froud, J., Johal, S., Leaver, A., Moran, M., \& Williams, K. (2011). City state against national settlement: UK economic policy and politics after the financial crisis. CRESC Working Paper Series, Working Paper No, 101.

Farías, I. (2011). The politics of urban assemblages. City, 15, 365-374.

Federici, S. (2004). Caliban and the witch. New York: Autonomedia.

Florida, R. (2005). Cities and creative class. London: Routledge.

Foucault, M. (1980). Questions on geography. In C. Gordon (Ed.), Power/knowledge: Selected interviews and other writings, 19721977 (pp. 63-77). New York: Pantheon Books.

Foucault, M. (2002). "Omnes et singulatim": Toward a critique of political reason. In J. Faubion (Ed.), Essential Works of Foucault, 1954-1984, Volume 3: Power (pp. 298-325). London: Penguin.

Foucault, M. (2010). The birth of biopolitics: Lectures at the Collège de France 1978-1979. Basingstoke: Palgrave Macmillan.

Foucault, M. (2013). Lectures on the will to know: Lectures at the Collège de France 1970-1971. Basingstoke: Palgrave Macmillan.

Friedmann, J., \& Wolff, G. (1982). World city formation: An agenda for research and action. International Journal of Urban and Regional Research, 6, 309-344.

Glassner, J-J. (2004). Du bon usage du concept de cité-état? Journal des Africanistes, 74, 35-48.

Gordon, C. (1991). Governmental rationality: An introduction. In G. Burchell, C. Gordon, \& P. Miller (Eds), The Foucault effect: Studies in governmentality (pp. 1-51). Chicago: University of Chicago Press.

Görz, A. (2012). Capitalism, Socialism, ecology. London: Verso.

Graham, S. (2010). Cities under siege: The new military urbanism. New York: Verso.

Guattari, F. (1984). Molecular revolution: Psychiatry and politics. London: Penguin Books.

Hardt, M., \& Negri, A. (2000). Empire. Cambridge, MA: Harvard University Press.

Hardt, M., \& Negri, A. (2005). Multitude: War and democracy in the Age of Empire. London: Penguin.

Hardt, M., \& Negri, A. (2017). Assembly. Oxford: Oxford University Press.

Harvey, D. (2003). The new imperialism. Oxford: Oxford University Press.

Harvey, D. (2006). Limits to capital. New York: Verso.

Harvey, D. (2010a). The enigma of capital, and the crisis of capitalism. Oxford: Oxford University Press.

Harvey, D. (2010b). A companion to capital. New York: Verso.

Harvey, D. (2013). Rebel cities. New York: Verso.

Harvey, D. (2015). Seventeen contradictions and the end of capitalism. London: Profile Books.

Hornborg, A. (2001). The power of the machine: Global inequalities of economy, technology, and environment. Lanham, MD: Rowman $\&$ Littlefield. 
Hornborg, A. (2009). Zero-sum world: Challenges in conceptualizing environmental load displacement and ecologically unequal exchange in the world-system. International Journal of Comparative Sociology, 50, 237-262.

Jacobs, J. (1970). The economy of cities. New York: Vintage.

Jacobs, J. (1985). Cities and the wealth of nations: Principles of economic life. New York: Vintage.

Jenkins, S. (2013). Who let this gulf on Thames scar London"s South Bank? Mayor Boris. The Guardian, 11 July.

Jessop, B. (1994). Post-Fordism and the state. In A. Amin (Ed.), Post-Fordism: A reader (pp. 251-279). Hoboken, NJ: Blackwell.

Jessop, B., Brenner, N., \& Jones, M. (2008). Theorizing sociospatial relations. Environment \& Planning D, 26, 389-401.

Lazzarato, M. (2015). Governing by debt. Los Angeles: Semiotext(e).

Lefèbvre, H. (1976). The survival of capitalism. New York: St Martin's Press.

Lefèbvre, H. (1991). The production of space. Oxford: Blackwell.

Long, N. (1972). The unwalled city: Reconstituting the urban community. New York: Basic Books.

Luxemburg, R. (2003). The accumulation of capital. London: Routledge.

Lynch, K. (1960). The image of the city. Cambridge, MA: MIT Press.

Mandeville, B. (1724/1989). The fable of the bees. London: Penguin.

Martines, L. (1980). Power and imagination: City-states in Renaissance Italy. New York: Vintage Books.

Marx, K. (1990). Capital: Volume 1. London: Penguin.

Marx, K. (1993). Grundrisse. London: Penguin.

Meiksins-Wood, E. (2003). Empire of capital. New York: Verso.

Meiksins-Wood, E. (2016). Democracy against capitalism: Renewing historical materialism. New York: Verso.

Mies, M. (1986). Patriarchy and accumulation on a world scale. London: Zed Books.

Mittelman, J. (1996). Rethinking the "new regionalism" in the context of globalization. Global Governance, 2, $189-213$.

Moore, J. (2015). Capitalism in the web of life. New York: Verso.

Müller, J-W. (2016). What is populism? Philadelphia, PA: University of Pennsylvania Press.

Negri, A. (1992). Marx beyond Marx. London: Pluto Press.

Negri, A. (2018). From the factory to the metropolis. Cambridge: Polity.

Offe, C. (1985). Disorganized capitalism. Cambridge: Polity.

Ohmae, K. (1990). The borderless world: Power and strategy in the interlinked economy. London: Harper Collins.

Pickford, J. (2013). Capital plots course to protect its global status. Financial Times, 13 March.

Reich, R. (1992). The work of nations: Preparing ourselves for $21^{\text {st }}$-century capitalism. New York: Vintage.

Ruggie, J. G. (1993). Territoriality and beyond: Problematizing modernity in international relations. International Organization, 47, 139-174.

Sabel, C., \& Piore, M. (1984). The second industrial divide. New York: Basic Books.

Sassen, S. (1991). The global city: New York, London, Tokyo. Princeton, NJ: Princeton University Press.

Sassen, S. (2000). The global city: Strategic site/new frontier. American Studies, 41, 79-95.

Sassen, S. (2001). The global city: New York, London, Tokyo. Princeton, NJ: Princeton University Press.

Sassen, S. (2006). Territory, authority, rights: From medieval to global assemblages. Princeton, NJ: Princeton University Press.

Smith, N. (1998). Antinomies of space and nature in Henri Lefebvre"s The Production of Space. In A. Light and J. M. SmithPhilosophy and geography II: The production of public space (pp. 49-70). Lanham, MD: Rowman \& Littlefield

Stäheli, U. (2003). The outside of the global. CR: The New Centennial Review, 3, 1-22.

Stäheli, U. (2012). Listing the global. Distinktion, 13, 233-246.

Tellmann, U., Opitz, S., \& Stäheli, U. (2012). Operations of the global. Distinktion, 13, 209-214.

Tilly, C. (1986). Space for capital, space for states. Theory and Society, 15, 301-309.

Tilly, C. (1990). Coercion, capital, and European states, AD 900-1990. Oxford: Blackwell.

Tilly, C. (1994). Entanglements of European cities and states. In C. Tilly \& W. P. Blockmans Cities and the rise of states in Europe, AD 1000 to 1800 (pp. 1-27). Boulder, CO: Westview Press.

Tonkiss, F. (2006). Contemporary economic sociology: Globalisation, production, inequality. London: Routledge.

Virilio, P. (2006). Speed and politics: An essay on dromology. Los Angeles: Semiotext(e). 
Wachsmuth, D., Madden, D., \& Brenner, N. (2011). Between abstraction and complexity: Meta-theoretical observations on the assemblage debate. City, 15, 740-750.

Walker, R. B. J. (1992). Inside/outside: International relations as political theory. Cambridge: Cambridge University Press.

Wallerstein, I. (1974). The rise and future demise of the world capitalist system: Concepts for comparative analysis. Comparative Studies in Society and History, 16, 387-415.

Welsh, J. (2017). Authoritarian governmentality through the global city: Contradictions in the political ecology of historical capitalism. Contemporary Politics, 23, 446-468.

Welsh, J. (2018). Cities, hinterlands, and critical theory. Political Geography, https://doi.org/10.1016/j.polgeo.2018. 03.004 .

Williams, R. (1976). Notes on Marxism in Britain since 1945. New Left Review, I/100, 81-94.

Yeung, H. (1998). Capital, state and space: Contesting the borderless world. Transactions of the Institute of British Geographers, 23, 291-309.

\section{AUTHOR'S BIOGRAPHY}

John Welsh is a researcher in the Department of Political \& Economic Studies at the University of Helsinki. His research agendas touch on the contemporary transformations of advanced capitalism, particularly in regard to planetary urbanisation, world ecology, and global cities, as well as in the governing of academic life. Recent work has appeared in Critical Horizons, Distinktion, Contemporary Politics and the International Journal of Politics, Culture \& Society.

How to cite this article: Welsh J. The political aesthetic of the British city-state: Class formation through the global city. Constellations. 2018;1-19. https://doi.org/10.1111/1467-8675.12369 